\title{
How Prepared are Hospital Employees for Internal Fire Disasters? A Study of an Indian Hospital
}

\author{
${ }^{1}$ Kasturi Shukla, ${ }^{2}$ Priyadarshini Chandrashekhar, ${ }^{3}$ Shweta Mehta
}

\begin{abstract}
Introduction: In case of internal disasters, such as fire in hospitals, health services to the community are severely hampered with the additional morbidity of victims, such as employees and visitors present when the disaster strikes. Risk assessment and fire preparedness are most crucial proactive measures to prevent fire disasters and minimize the loss in a hospital; however, scanty studies are available on this topic.
\end{abstract}

Materials and methods: This cross-sectional study was conducted at a multispecialty hospital in Mumbai, Maharashtra (India), during March-April 2014. Fire-Safety Preparedness Framework (FSPF) was designed with four domains (risk and vulnerability assessment, response mechanisms and strategies, preparedness plan and information management) for evaluation of fire safety preparedness of hospital employees. Baseline variables were summarized; instrument was tested for reliability using Cronbach's alpha and content validity through review by experts. The number of correct responses for each question was further analyzed across the type of employee.

Results: The instrument showed high reliability (Cronbach's alpha $=0.89, p$-value $\leq 0.01)$ and content validity. A total of 207 employees (mean age $32 \pm 8.3$ years, 63\% females) consented and participated in the study. Out of 20 questions, awareness was high ( $\geq 90 \%)$ only for three questions from "Response mechanism and strategies" domain. For the remaining questions, awareness was moderate to low. The awareness varied highly with the type of employee.

Conclusion: The FSPF is a reliable tool for application in the Indian context for hospital employees. Disaster preparedness training and drill need to involve employees from all departments as awareness levels varied highly with type of employee.

Keywords: Disaster preparedness, Fire safety, Hospital.

How to cite this article: Shukla K, Chandrashekhar P, Mehta S. How Prepared are Hospital Employees for Internal Fire Disasters? A Study of an Indian Hospital. Int J Res Foundation Hospc Health Adm 2016;4(1):20-24.

Source of support: Nil

Conflict of interest: None

\footnotetext{
${ }^{1}$ Assistant Professor, ${ }^{2,3}$ Student

${ }^{1}$ Department of Health Care Management, Symbiosis Institute of Health Sciences (Symbiosis International University), Pune Maharashtra, India

2,3Symbiosis Institute of Health Sciences (Symbiosis International University), PGPHS, Sancheti Healthcare Academy, Pune Maharashtra India

Corresponding Author: Kasturi Shukla, Assistant Professor Department of Health Care Management, Symbiosis Institute of Health Sciences (Symbiosis International University) Pune Maharashtra, India, Phone: +918308964201 e-mail: kasturiagnihotri@rediffmail.com
}

\section{INTRODUCTION}

One of the criteria used by the Pan American Health Organization (PAHO) and the World Health Organization (WHO) to define a Safe Hospital is one that "is organized, with contingency plans in place and health workforce trained to keep the network operational." ${ }^{11}$ A hospital is prone to three types of disasters, namely, community affected - hospital unaffected, community unaffected hospital affected, and community affected - hospital affected. The second category of "community unaffected hospital affected" is also known as an internal disaster, such as fire and terrorist attack. In case of hospitals being affected by disasters, the health services to the community are severely hampered with the additional morbidity load of the disaster victims, such as employees and visitors present when disaster struck.

However, the situation can be controlled relatively sooner if employees are well versed with the necessary actions to be taken in terms of response mechanisms and strategies, preparedness plan, and information management for quick evacuation and triage. The components of a disaster response cycle include risk assessment and preparedness, response, rescue, recovery, mitigation, risk reduction, out of which the most important component is being proactive with a contingency plan to deal with the disaster. ${ }^{2}$ In hospitals, preparedness includes preparation and circulation of a disaster manual that addresses the action plan. However, there have been only a few studies examining the level of preparedness of hospitals for an urgent evacuation, and Indian studies are hard to find. ${ }^{3}$ The present study has been conducted to assess the level of fire safety preparedness of employees of an Indian hospital.

\section{MATERIALS AND METHODS}

\section{Study Design and Setting}

This cross-sectional study was conducted on employees of a multispecialty hospital in Mumbai, Maharashtra (India), from March to April 2014, after obtaining permission from the hospital authorities and written consent from employees.

\section{Study Procedure, Instrument, and Scoring}

All employees of the hospital under the following categories were provided a questionnaire: Doctors, nurses, 
administrative staff, engineers and maintenance (E\&M), and security personnel. Those who consented to participate in the study and completed the questionnaire were included.

The safety manual of the hospital that was being followed for fire safety preparedness in the hospital was studied in detail. In addition to this, the disaster preparedness training program of International Federation of Red Cross ${ }^{4}$ was referred to design the Fire-Safety Preparedness Framework (FSPF) for evaluation of fire safety preparedness of hospital employees. The FSPF questionnaire comprised 20 questions pertaining to four domains, namely, risk and vulnerability assessments (Q. 1,2,4), response mechanisms and strategies (Q. 8, 9, $14,19)$, preparedness plan (Q. 3, 5, 7, 10, 15, 16, 20), and information management (Q. 6, 11, 12, 13, 17, 18). Questions 1 to 3 are evaluated on Yes/No/Can't say scale. The remaining questions had four options, out of which one was the correct answer.

\section{Data Analysis}

The baseline variables were summarized using an appropriate measure of central tendency. The reliability of the questionnaire was tested using Cronbach's alpha. For qualitative content validity, a group of experts was interviewed for suitability and comprehensiveness of questions. The scores were computed based on the scoring guidelines mentioned before. The number of correct responses for each question was further analyzed across the type of employee.

\section{RESULTS}

The questionnaire was preliminarily validated and approved by a team consisting of the medical superintendent, quality officer, hospital administrator, facility director, and safety committee of the hospital. All the experts approved the comprehensiveness and suitability of questions, thus, indicating high content validity. The questionnaire was then distributed to 230 hospital employees to assess their fire safety preparedness. A total of 207 employees (90\%) who provided consent were included in the study.

Of these 207 employees, 130 (63\%) were females and mean age of the sample was $32 \pm 8.3$ years. Mean work experience of the employees in the hospital was $4 \pm 0.54$ years and the mean time since last training attended by the employees for fire safety was $1.6 \pm 1.5$ years. Included in the sample were 40 doctors (19\%), 82 nurses (40\%), 31 administrative staff (15\%), 20 E\&M staff (9.6\%), and 34 security personnel (16.4\%).

Results of reliability analysis of the instrument are shown in Table 1. The reliability of the questionnaire was tested with overall Cronbach's alpha of 0.89 (p-value $\leq 0.01)$ revealing high internal consistency. However, for the questions 1, 2, and 4 in the Risk and Vulnerability Assessment domain, the "corrected item-total correlations" were low. When, the reliability test was repeated by dropping these questions and the negatively scored items, the Cronbach's alpha of the instrument increased from 0.89 to 0.92 . Hence, these were identified as weak questions.

Table 2 represents the frequency of optionwise response for each of the questions. The correct response

Table 1: Reliability results of the questionnaire

\begin{tabular}{lc}
\hline Questions/items & $\begin{array}{c}\text { Corrected item- } \\
\text { total correlation }\end{array}$ \\
\hline vomain 1: Risk and vulnerability assessment \\
1 Did the hospital face any fire disaster in the past? & 0.43 \\
2 Does your hospital have a disaster plan? & 0.31 \\
4 Does the hospital have a Safety Committee? & 0.39 \\
Domain 1 Cronbach's alpha=0.52 (p-value<0.001) & 0.57 \\
Domain 2: Response mechanisms and strategies & 0.77 \\
8 Means of going down in case of fire breakout on 3rd floor of hospital & 0.75 \\
9 Means used to find way in dark in case of emergency & 0.7 \\
14 Action to be taken on discovering fire & 0.7 \\
19 What is the first step while using fire extinguisher? & 0.54 \\
Domain 2 Cronbach's alpha=0.68 (p-value<0.001) & 0.86 \\
Domain 3: Preparedness plan & 0.75 \\
3 Have you attended any workshops/training related to disasters/emergencies? & 0.64 \\
5 What is the correct position while firefighting in a closed area & 0.68 \\
7 Type of fire extinguisher used in case of short circuit & 0.69 \\
10 Location of the grab kit in conjunction with the employee work station & 0.52 \\
15 What is the location of the assembly point? & 0.69 \\
16 Location of the nearest fire exit in conjunction with the work station & 0.71 \\
20 Type ABC fire extinguishers are safe to use on which type/s of fire? & 0.8 \\
Domain 3 Cronbach's alpha=0.83 (p-value<0.001) & 0.8
\end{tabular}

(Cont'd...) 
(Cont'd...)

\begin{tabular}{ll}
\hline Questions/items & $\begin{array}{c}\text { Corrected item- } \\
\text { Alpha } \\
\text { total correlation } \\
\text { value }\end{array}$ \\
\hline Domain 4: Information management & 0.88 \\
6 What is the code to be announced in case of fire emergency at the hospital? & 0.91 \\
11 Which sections'/departments' number should be dialed first for internal reporting in case of fire? & 0.85 \\
12 When do the sprinklers get activated? & 0.82 \\
13 Where is the Fire Control Panel located in the hospital? & 0.8 \\
17 What color tag must be provided to triage patients who require URGENT care? & 0.75 \\
18 Who is evacuated FIRST in case of a fire disaster from site of incident to assembly area? & 0.87 \\
Domain 4 Cronbach's alpha $=0.88$ ( $p$-value $<0.001)$ & 0.89 \\
Overall Cronbach's alpha $=0.89(p$-value $<0.01)$ & 0.85 \\
\hline
\end{tabular}

Table 2: Domain-wise frequency $(n, \%)$ of responses $(n=207)$

\begin{tabular}{|c|c|c|c|c|c|}
\hline \multirow{2}{*}{\multicolumn{2}{|c|}{$\begin{array}{l}\text { Q. no. Question } \\
\text { Domain 1: Risk and vulnerability assessment }\end{array}$}} & \multicolumn{4}{|c|}{ Response $n(\%)$} \\
\hline & & & & & \\
\hline 1 & $\begin{array}{l}\text { Did the hospital face any fire } \\
\text { disaster in the past? }\end{array}$ & Yes $5(3)$ & No 184 (89) & Can't say $6(3)$ & $\begin{array}{l}\text { No response } \\
10(5)\end{array}$ \\
\hline 2 & $\begin{array}{l}\text { Does your hospital have a disaster } \\
\text { plan? }\end{array}$ & Yes $199(96)$ & No $0(0)$ & Can't say $4(2)$ & $\begin{array}{l}\text { No response } \\
4(2)\end{array}$ \\
\hline 4 & $\begin{array}{l}\text { Aware about the presence of safety } \\
\text { committee of the hospital }\end{array}$ & Yes $193(93)$ & No $8(4)$ & Can't say $4(2)$ & $\begin{array}{l}\text { No response } \\
2(1)\end{array}$ \\
\hline \multicolumn{6}{|c|}{ Domain 2: Response mechanisms and strategies } \\
\hline 8 & $\begin{array}{l}\text { Means of going down in case of fire } \\
\text { breakout on 3rd floor of hospital }\end{array}$ & Stairs 195 (94) & Lift $0(0)$ & Both $10(5)$ & $\begin{array}{l}\text { No response } \\
2 \text { (1) }\end{array}$ \\
\hline 9 & $\begin{array}{l}\text { Means used to find way in dark in } \\
\text { case of emergency }\end{array}$ & $\begin{array}{l}\text { Nearest switch board } \\
7(3)\end{array}$ & Your cell phone $4(2)$ & $\begin{array}{l}\text { Floro-luminous } \\
\text { indicators } 186(90)\end{array}$ & $\begin{array}{l}\text { No response } \\
10(5)\end{array}$ \\
\hline 14 & $\begin{array}{l}\text { Action to be taken on discovering } \\
\text { fire }\end{array}$ & $\begin{array}{l}\text { Inform the manager } \\
2(1)\end{array}$ & $\begin{array}{l}\text { Wait for detector to } \\
\text { activate alarm } 2(1)\end{array}$ & $\frac{\text { Raise alarm }}{199(96)}$ & $\begin{array}{l}\text { No response } \\
4(2)\end{array}$ \\
\hline 19 & $\begin{array}{l}\text { What is the first step while using } \\
\text { fire extinguisher }\end{array}$ & $\begin{array}{l}\text { Aim toward extinguisher } \\
27 \text { (13) }\end{array}$ & Pull the pin $153(74)$ & $\begin{array}{l}\text { Check if extinguisher } \\
\text { is full } 25(12)\end{array}$ & $\begin{array}{l}\text { No response } \\
2 \text { (1) }\end{array}$ \\
\hline \multicolumn{6}{|c|}{ Domain 3: Preparedness plan } \\
\hline 3 & $\begin{array}{l}\text { Training attended for any disaster/ } \\
\text { emergency }\end{array}$ & Yes 197 (95) & No $8(4)$ & Can't say $2(1)$ & $\begin{array}{l}\text { No response } \\
0(0)\end{array}$ \\
\hline 5 & $\begin{array}{l}\text { What is the correct position while } \\
\text { fire-fighting in a closed area }\end{array}$ & Exit $157(76)$ & Along wind $15(7)$ & $\begin{array}{l}\text { Away from wind } \\
35 \text { (17) }\end{array}$ & $\begin{array}{l}\text { No response } \\
0(0)\end{array}$ \\
\hline 7 & $\begin{array}{l}\text { Type of fire extinguisher used in } \\
\text { case of short circuit }\end{array}$ & $\frac{\mathrm{CO}_{2}}{176}, \frac{\mathrm{DCP}, \mathrm{ABC} \text { powder }}{(85)}$ & $\begin{array}{l}\text { Water, ABC, Foam } \\
10(5)\end{array}$ & Both $6(3)$ & $\begin{array}{l}\text { No response } \\
15(7)\end{array}$ \\
\hline 10 & $\begin{array}{l}\text { Location of the grab kit in } \\
\text { conjunction with the employee } \\
\text { work station }\end{array}$ & Correct $72(35)$ & Wrong $104(50)$ & No response 31 (15) & \\
\hline 15 & $\begin{array}{l}\text { What is the location of the } \\
\text { assembly point }\end{array}$ & Correct 147 (71) & Wrong 25 (12) & No response 35 (17) & \\
\hline 16 & $\begin{array}{l}\text { Location of the nearest fire exit in } \\
\text { conjunction with the work station }\end{array}$ & Correct $153(74)$ & Wrong $29(14)$ & No response 25 (12) & \\
\hline 20 & $\begin{array}{l}\text { For which type of fire is the } A B C \\
\text { fire extinguisher used? }\end{array}$ & $\begin{array}{l}\text { Ordinary combustibles } \\
31(15)\end{array}$ & $\begin{array}{l}\text { Flammable liquids } \\
35(17)\end{array}$ & All types $122(59)$ & $\begin{array}{l}\text { No response } \\
19(9)\end{array}$ \\
\hline \multicolumn{6}{|c|}{ Domain 4: Information management } \\
\hline 6 & $\begin{array}{l}\text { Code to be announced in case of } \\
\text { fire emergency in hospital }\end{array}$ & Code Pink 75 (36) & Code Purple 2 (1) & $\underline{\text { Code Red } 118 \text { (57) }}$ & $\begin{array}{l}\text { No response } \\
12(6)\end{array}$ \\
\hline 11 & $\begin{array}{l}\text { Which sections/departments } \\
\text { number should be dialed first for } \\
\text { internal reporting in case of fire? }\end{array}$ & Operator 39 (19) & $\begin{array}{l}\text { Public address } \\
\text { system } 135(65)\end{array}$ & Security $15(7)$ & $\begin{array}{l}\text { No response } \\
18(9)\end{array}$ \\
\hline 12 & $\begin{array}{l}\text { When do the sprinklers get } \\
\text { activated? }\end{array}$ & $\begin{array}{l}\text { Smoke in an area } \\
59(28)\end{array}$ & $\begin{array}{l}\text { Activation of a pull } \\
\text { station } 72(35)\end{array}$ & $\underline{\underline{\text { Heat from fire }}}$ & $\begin{array}{l}\text { No response } \\
12(6)\end{array}$ \\
\hline 13 & $\begin{array}{l}\text { Location of the fire control panel in } \\
\text { the hospital }\end{array}$ & $\frac{\text { Building Management }}{\underline{\text { System (BMS) } 77(37)}}$ & Security 88 (42) & IT $21(10)$ & $\begin{array}{l}\text { No response } \\
21(10)\end{array}$ \\
\hline 17 & $\begin{array}{l}\text { Triage color code for Urgent care } \\
\text { patients }\end{array}$ & Yellow 37 (18) & $\underline{\text { Red } 151(73)}$ & Green 2 (1) & $\begin{array}{l}\text { No response } \\
17(8)\end{array}$ \\
\hline 18 & $\begin{array}{l}\text { Color tag of the patient to be } \\
\text { evacuated first from disaster site to } \\
\text { assembly area }\end{array}$ & Green tag $43(21)$ & Yellow tag $10(5)$ & $\underline{\text { Red tag } 135(65)}$ & $\begin{array}{l}\text { No response } \\
19(9)\end{array}$ \\
\hline
\end{tabular}

The correct responses are underlined. No response means that the question was left blank 
for each question is underlined. For question 1, 89\% respondents were correct in saying that the hospital has not faced any fire disasters in past. Similarly, in question 2 , $96 \%$ respondents correctly responded that the hospital has a well-defined disaster plan pertaining to fire safety. Out of 20 questions, awareness was high ( $\geq 90 \%$ ), only for three questions from domain 2 "response mechanism and strategies". For domain 2, range (in \%) of correct responses was 74 to $96 \%$ showing highest awareness for this domain. The proportion of correct responses for domain 3 "Preparedness Plan" was low for two questions - location of grab kit (35\%) and type of fire for which ABC extinguisher is used (59\%). Range of correct responses was 71 to $85 \%$ for remaining questions under domain 3. The proportion of correct responses for domain 4 "Information Management" was low to moderate for almost all questions ranging from 18 to $65 \%$, except for one question on triage color code for urgent care with $73 \%$ correct responses. Hence, the awareness level was usually moderate to poor among hospital employees.

Graph 1 shows the proportion of correct responses across various types of employees interviewed, such as doctors, nurses, engineering and maintenance (E\&M), administration, and security. Questions 1 to 3 are not included in the graph as there are no correct answers for these questions.

The staff members from E\&M and administration were observed to be most aware about the fire safety guidelines. This may be largely because they are involved in purchasing and/or installation of the equipment. Security staff was aware about the guidelines for the areas pertaining to their functioning, but their awareness was low. Nursing staff was better aware regarding the questions on triage and those pertaining to their work stations and day-to-day activities. Doctors, many of whom are visiting consultants, had marginal knowledge regarding

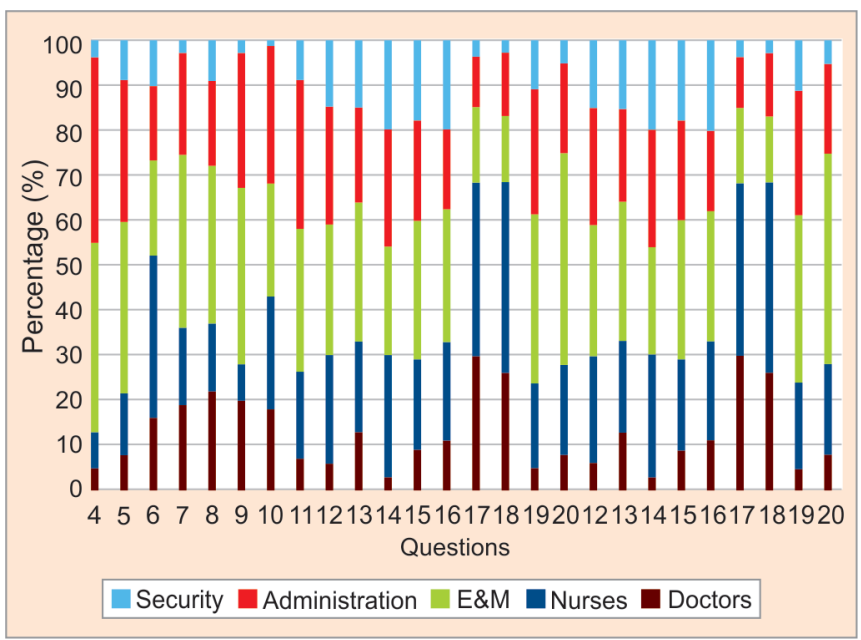

Graph 1: Graphical representation of distribution of correct responses (in \%) across category of staff fire safety issues. However, they had sound knowledge about the questions on triage and emergency situation.

\section{DISCUSSION}

The present study was conducted with the objective of evaluating fire safety preparedness among the employees of an Indian hospital. The Fire-Safety Preparedness Framework (FSPF) questionnaire was found to be reliable for application in the Indian context for hospital employees. Questions 1, 2, and 4 in the risk and vulnerability assessment domain were identified as weak questions and should be dropped for future studies.

The overall preparedness score regarding the various factors on fire safety was low to moderate. Highest awareness was observed for domain 2 "response mechanism and strategies" with awareness level $>90 \%$ except for one question. As much as $95 \%$ employees had attended fire safety training. However, as the mean time since last training attended was 1.6 years, the time gap is high. Previous studies have shown that training develops skills and knowledge to handle the disaster. ${ }^{5}$ Refresher courses must be carried out every 4 to 6 months to refresh the memory of employees. To increase the performance and participation in the training programs, the awareness levels about fire safety preparedness may be linked to the performance appraisal of the employees. However, staff must be made more aware about the issues covered in "Information Management" and "Preparedness Plan" domains.

Doctors were found to have sound knowledge about the questions on triage and emergency situation. Administration and E\&M staff was better aware about the installation and location aspects. However, we could not find any study in literature regarding variation of preparedness awareness across type of staff to compare our results with.

It is recommended that disaster management committee should include staff from all cadres. Initiative should be taken by this committee to educate and inform all staff members regarding safety preparedness guidelines. Further, mock drills with all staff members should be conducted regularly, preferably on rotation basis to cover all employees.

The hospital should also have some tie ups with other nearby health facilities that can be contacted in case of an internal disaster in hospitals. ${ }^{6}$ The employees must be aware about these health facilities where the critical patients can be shifted in case of an internal disaster. Further, services of these facilities can be immediately availed to transfer critical patients of the affected hospital. The employees and other visitors of the affected hospital can also be treated at these facilities. 
The strength of our study is that we validated the questionnaire on 207 employees of a multispecialty Indian hospital. To the best of our knowledge, we could not find any similar studies that analyze the safety preparedness of hospital employees across different cadres. The probable weakness of the study is that the analysis was done at a basic level. The second phase of the study is planned for high fire-prone areas for analysis of preparedness of the staff posted there.

\section{CONCLUSION}

The Fire-Safety Preparedness Framework (FSPF) is reliable for application in an Indian context for hospital employees. Disaster preparedness training and drill need to involve employees from all departments as awareness levels varied highly with type of employee. Internal disaster may strike any time and employees need to be vigilant and aware to handle such situations. Training and refresher programs should be conducted more frequently and may be linked with annual performance appraisal for better participation and receptivity.

\section{REFERENCES}

1. National Disaster Management Guidelines (Draft): Hospital Safety. National Disaster Management Authority. Government of India Document; 2013 Dec (accessed 2014 Dec 5). Available from: www.ndma.gov.in/images/pdf/NDMA hospitalsafety.pdf.

2. Talati S, Bhatia P, Kumar A, Gupta AK, Ojha D. Strategic planning and designing of a hospital disaster manual in a tertiary care, teaching, research and referral institute in India. World J Emerg Med 2014;5(1):35-41.

3. Murphy GR, Foot C. ICU fire evacuation preparedness in London: a cross-sectional study. Br J Anesth 2011 May; 106(5):695-698.

4. Disaster Preparedness Training Programme. Introduction to Disaster preparedness International Federation of Red Cross and Red Crescent Societies; 2000 Jun (accessed 2014 Mar 9). Available from: http://www.ifrc.org/Global/Introdp.pdf.

5. Williams J, Nocera M, Casteel C. The effectiveness of disaster training for health care workers: a systematic review. Ann Emerg Med 2008 Sep;52(3):211-222.

6. World Health Organization. Hospital emergency response checklist. An all-hazards tool for hospital administrators and emergency managers. WHO Regional Office for Europe; 2011 (accessed 2014 Oct 18). Available from: http://www.euro.who. int/__data/assets/pdf_file/0020/148214/e95978.pdf?ua=1. 